\title{
Порівняльна оцінка візуалізації при виконанні симультанного лапароскопічного лікування жовчнокам'яної хвороби та грижі стравохідного отвору діафрагми
}

\begin{abstract}
Мета роботи: визначити та оцінити візуалізацію при виконанні звичайних лапароскопічних операцій та симультанних лапароскопічних операцій при лікуванні жовчнокам’яної хвороби (ЖКХ) та грижі стравохідного отвору (ГСОД). Визначити переваги і недоліки методик. Оцінити вплив вибору техніки лапароскопічних операцій на ергономіку під час виконання операційного прийому.

Матеріали і методи. На базі ВОКЛ ВІМДЛ у період з 2013 до 2019 р. 156 пацієнтів пройшли лікування, яким виконували лапароскопічну крурорафію з фундоплікацією за Тупе та симультанну лапароскопічну холецистектомію 3 використанням власної розробленої техніки. Порівняння з результатами лікування ЖКХ “французьким” методом. Використано методику з нульовою гіпотезою, аналіз за Пірсоном, Тьюкі, Манна-Уїтні.

Результати досліджень та їх обговорення. Різниця відстані між портами для астенічного та гіперстенічного типу статури склали 4,4 см і 3,0 см, зона візуалізації $(12,44 \pm 4,01)$ та $(9,54 \pm 2,27)$ см² $^{2}$ що статистично значуще (р=0,715)), кут між інструментами $(62,31 \pm 7,35)^{\circ}$ та $(57,29 \pm 6,764){ }^{\circ}$, відстань наближення лапароскопа до об’єкта операції складає $(3,54 \pm 0,47)$ см та $(3,41 \pm 0,478)$ см для дослідної та контрольної груп відповідно. Виконання симультанного лапароскопічного втручання не призводить до погіршення візуалізації та збільшує комфорт під час симультанної операції порівняно із холецистектомією “французьким” методом. Використання власної симультанної техніки не призводить до погіршення післяопераційних наслідків. Розроблена на базі ВІМДЛ ВОКЛ методика є достатньо ефективною і придатною до запровадження.
\end{abstract}

Ключові слова: жовчнокам’яна хвороба; грижі стравохідного отвору діафрагми; симультанна хірургія; лапароскопія.

Постановка проблеми і аналіз останніх досліджень та публікацій. На даний момент 30 \% від усіх хірургічних патологій дорослого населення Європи становить жовчнокам'яна хвороба (ЖКХ). У 14 \% хворих наявна супутня хірургічна патологія. Актуальна стратегія лікування холецистолітіазу, переглянута в Токіо 2018 року (Tokio Guideline 08/13/18), вказує на необхідність лікування холецистолітіазу операційно у плановому порядку у найкоротший час. Зважаючи на часте випадкове діагностування цієї патології під час планового огляду або огляду направленого на іншу патологію, актуальним $€$ розробка маршруту лікування таких пацієнтів. Зрозуміло, що можливість одномоментного операційного лікування пацієнтів із поєднаною хірургічною патологією органів черевної порожнини надає велику перевагу для пацієнта та хірурга. Рекомендації ВООЗ, опубліковані на офіційній вебсторінці, підтверджують і продовжуть курс галузі охорони здоров’я на скорочення сумарного часу перебування у стаціонарі та кількості звернень з будь-яких причин до медичних установ, а також обмеження використання атибіотиків та антибактеріальних препаратів. Усім цим критеріям відповідає симультанний підхід. Наша робота спрямована на аналіз методів лікування ЖКХ із грижею стравохідного отвору діафрагми (ГСОД). Надаємо дані з операційного лікування таких хворих шляхом виконання симультанних операційних втручань, напрацьовані в умовах відділення інвазивних методів діагностики та лікування Волинської обласної клінічної лікарні (ВІМДЛ ВОКЛ). Також у роботі порівнюються ефективність, безпека, швидкість i етапність, а також доцільність симультанного підходу при лікуванні ЖКХ та ГСОД.

Мета роботи: визначити та оцінити візуалізацію, доступність до об’єкту операції, візуалізацію зони операції та ергономічні умови при виконанні звичайних лапароскопічних операцій та симультанних лапароскопічних операцій при лікуванні ЖКХ та ГСОД. Визначити переваги і недоліки методик. Оцінити вплив ергономіки на виконання оперативного маневру.

Матеріали і методи. Впродовж 2013-2019 р. проведено ретроспективний збір даних пацієнтів, яким було виконано лапароскопічні симультанні операції для лікування жовчнокам'яної хвороби та грижі стравохідного отвору діафрагми використовуючи власну розроблену техніку симультанних операцій, таких хворих було 156 (група 1). Порівняння техніки проводили зі звичайною “французькою” методикою лапароскопічної холецистектомії (група 2). В умовах експерименту ви- 
вчали: площу візуалізації; відстань між центрами кистей хірурга, який маніпулює одночасно двома інструментами; відстань наближення лапароскопа до операційної ділянки та кут між основними робочими інструментами.

Дані про пацієнтів, результати лабораторних та інструментальних методів дослідження, а також результати операційних втручань вносили в карти обстеження хворих (типова форма журналу, затверджена у Тернопільському національному медичному університеті імені І. Я. Горбачевського). На основі карт створено електронну базу даних пацієнтів. Для введення даних застосовували програму Microsoft Office Excel 2010 SP1 (Microsoft corp., 2010). За допомогою функції YEARFRAC (поч_дата; кін_дата; базис) в Excel визначали й вік пацієнтів в день шпиталізації. Дані про результати лікування “французькою” методикою отримано з досліджень наших колег [12].

Статистичний аналіз результатів дослідження проводили з використанням програми SPSS 16.0.1 for Windows (SPSS Inc., Chicago, IL, USA). За допомогою програми здійснювали структурування, перевірку даних, дескриптивний аналіз та аналітичну статистику. Статистичну обробку даних проводили згідно зі статистичними рекомендаціями від 21.11.2008 загальновідомого рейтингового періодичного видання “Nature medicine”.

Про відсутність взаємозв’язку або кореляції між дослідними змінними, про відсутність значущих відмінностей у розподілах вибірок, про відсутність впливу факторів на змінну при використанні аналітичних методів статистики приймалась гіпотеза 0 (нульова). Застосовували для перевірки гіпотези про нормальний розподіл змінних величин за допомогою теста Колмогорова-Смірнова. Взаємозв’язок між змінними вивчали за допомогою кореляційного аналізу за Пірсоном. Застосовували рангову кореляцію за Спірманом у випадку, коли хоча б одна зі змінних мала порядкову шкалу, або не була нормально розподілена. Для змінних величин, які належать до інтервальної шкали та підпорядковуються нормальному розподілу, визначали середнє значення та стандартне відхилення. Для порівняння середніх значень застосовували t-тест для незалежних вибірок, а також t-тест для парних вибірок з 95 \% довірчим інтервалом різниці середніх. Процедуру порівняння середніх значень трьох зв'язаних вибірок здійснювали шляхом дисперсійного аналізу з повторними вимірюваннями, а також багатомірного дисперсійного аналізу (MANOVA). При цьому використовували апостеріорні тести: критерій Тьюкі та LSD-тест (найменша значуща різниця). У випадку, коли дані не підпорядковувались нормальному розподілу, визначали медіану, нижній і верхній квартилі та застосовували непараметричний U-тест Манна-Уїтні. Для порівняння категоріальних даних застосовували $\chi^{2}$-тест, а також U-тест Манна-Уїтні. Визначали двосторонній рівень значущості. Прийнятною межею статистичної значущості вважали рівень $\mathrm{p} \leq 0,05$. Результати 3 рівнем $\mathrm{p} \leq 0,01$ розглядали як статистично значущі, з рівнем $\mathrm{p} \leq 0,001$ - як високозначущі.

Результати досліджень та їх обговорення. При аналізі статистичних даних, отриманих після обробки наших показників, викорисовуючи кореляцію за Пірсоном та багатомірний дисперсійний аналіз (MANOVA), можна побачити, що наш власний метод виконання симультанних лапароскопічних операції, при поєднанні ЖКХ та ГСОД не відрізняється від стандартного “французького” методу виконання лише лапароскопічної холецистектомії за комфортом, при цьому забезпечує більшу ділянку візуалізації, а також дає можливість хірургу та асистенту працювати в більш комфортних умовах, не набуваючи неергономічного положення, що збільшують рівень психоемоційного та фізичного напруження. Наш власний метод введення портів для виконання симультанних операційних втручань (рис. 1,2 ) дає можливість значно знизити втому під час та після операції на хірургічну бригаду порівняно зі звичайним “французьким” методом. Статистично і практично додведено, що спосіб розміщення хірургів та портів для проведення лапароскопічних операцій, як вказано на рисунку 1, є найбільш оптимальним через те, що забезпечує можливість операційних дій в ділянках виконання холецистектомії і крурорафії з фундоплікацією, при цьому не $€$ менш комфортним за стандартний метод лапароскопічної холецистектомії.

Порівняльна оцінка способів лапароскопічної холецистектомиі

Дослідження проведено на базі Волинської обласної клінічної лікарні в умовах відділення інвазивних методів діагностики та лікування та на базі ФПО Тернопільського національного медичного університету імені I. Я. Горбачевського.

За ділянку операційної дії при лапароскопічній холецистектомії визначено сектор кола (обмежений передньою черевною стінкою та частково діафрагмою) на площині вісцеральної поверхні печінки, центром якого є крайня верхня точка на дні жовчного міхура, а при виконанні операційного втручання з приводу ГСОД - сектор із межами діафрагми, кругла та серпоподібна зв’язки печінки, стравохід, шлунок, медіальний край селезінки, а радіусом - відстань між робочими кінцями інструментів, якими здійснюється операційний вплив. 


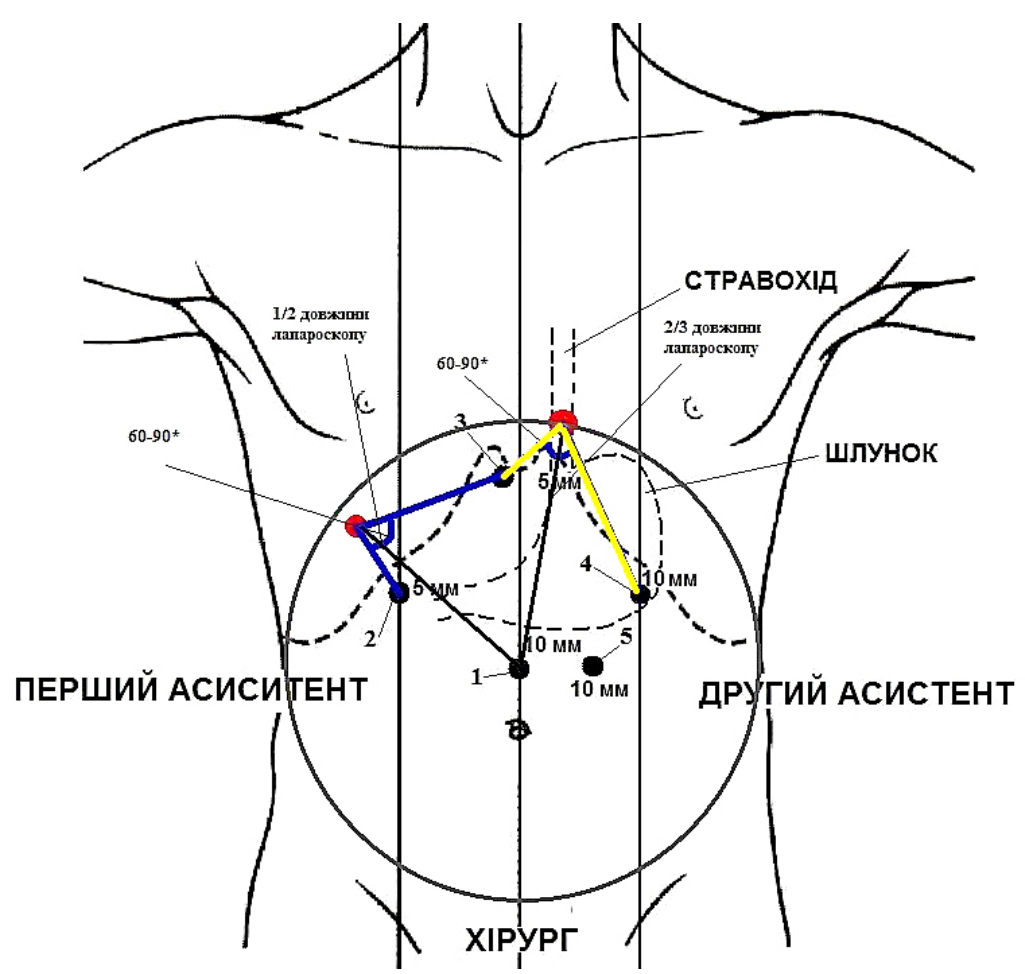

Рис. 1. Розміщення операційної бригади при виконанні лапароскопічної крурорафії з фундоплікацією: 1-10 мм порт для лапароскопа та виведення препарату на завершальному етапі операції; 2 - 5 мм порт для ретрактора печінки, асистента під час крурорафії та фундоплікації і для інструмента хірурга під час холецистектомії; 3-5 мм порт для інструмента хірурга під час крурорафії та фундоплікації та холецистектомії (при переході через той же розріз шкіри перебивається на іншу сторону круглої зв’язки для мінімізації опору м’язово-апоневротичного шару та ризиків розриву тканин натягом, включно Глісонову капсулу); 4-10 мм порт для інструмента хірурга під час крурорафії та фундоплікації (для використання LigaSure ${ }^{\mathrm{TM}}$ та Endo Stitch ${ }^{\mathrm{TM}}$ ). 5 - 5-10 мм порт для інструмента асистента, а саме для низведення шлунка.

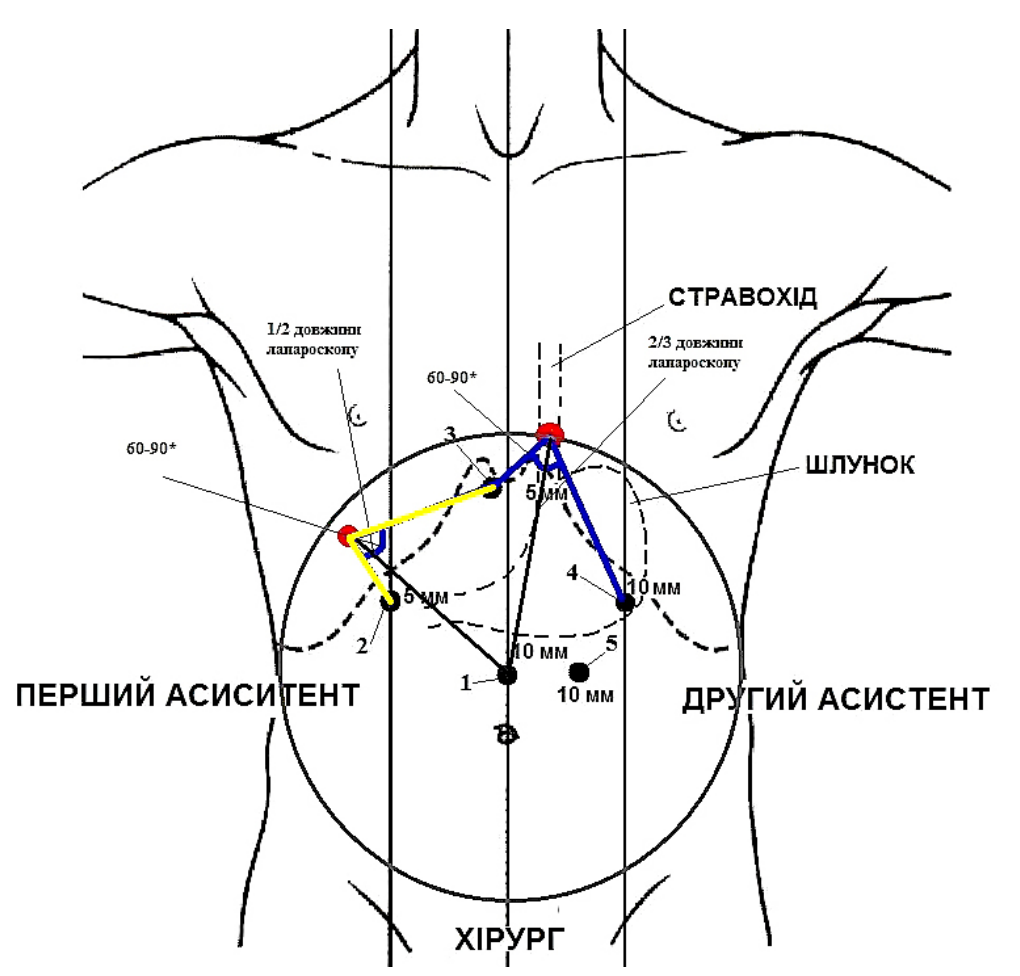

Рис. 2. Розміщення операційної бригади при виконанні лапароскопічної холецистектомії. 
Проект дослідження передбачав визначення площі зони візуалізації, відстані між центрами кистей хірурга, який здійснює бімануальні маніпуляції, відстані наближення лапароскопа до операційної ділянки та кута між основними робочими інструментами у двох групах - відповідно до способу симультанного операційного втручання: I група - власний спосіб, II група - “французький” спосіб. Для кожного способу досліджувані параметри визначали у трьох підгрупах, які відрізнялись розташуванням портів - відповідно до нормостенічного, гіпер- та астенічного типів статури. При цьому різниця відстані між портами для гіперстенічного та астенічного типів при “французькому” способі становила 4,4 см, а при власному способі - 3,0 см.

Для виконання експерименту використовували ендовідеосистему MGB, лапароскопи з кутом спостереження $0^{\circ}$ та $30^{\circ}$ та лапароскопічні інструменти фірми Karl Storz, Olympus, Covidien (Medtronic) (LigaSure), AutoSuture (EndoStich).

За результатами дослідження, наведеними у таблиці 1, зона візуалізації об’єкта операції зростає зі збільшенням свободи руху лапароскопа i відсутністю фехтування.

Отже, результати статистичного аналізу свідчать, що для кожного зі способів симультанного

Таблиця 1. Показники дослідних параметрів та результати статистичного аналізу

\begin{tabular}{|c|c|c|c|c|c|c|c|}
\hline \multirow{2}{*}{\multicolumn{2}{|c|}{$\begin{array}{c}\text { Спосіб лапароскопічної } \\
\text { холецистектомії }\end{array}$}} & \multicolumn{3}{|c|}{ “Французький” } & \multicolumn{3}{|c|}{ Власний (n=156) } \\
\hline & & нормост. & гіперст. & астен. & нормост. & гіперст. & астен. \\
\hline \multirow{2}{*}{$\begin{array}{l}\text { Кореляція } \\
\text { за Пірсоном } \\
\text { у підгрупах } \\
\text { (двосторонній } \\
\text { рівень значущості) }\end{array}$} & Гіперст. & $\begin{array}{c}\mathrm{r}=0,957^{* *} ; \\
\mathrm{p}<0,001\end{array}$ & - & - & $\begin{array}{c}\mathrm{r}=0,974^{* *} ; \\
\mathrm{p}<0,001\end{array}$ & - & - \\
\hline & Астен. & $\begin{array}{c}\mathrm{r}=0,982^{* *} ; \\
\mathrm{p}<0,001\end{array}$ & $\begin{array}{c}\mathrm{r}=0,989 * * \\
\mathrm{p}<0,001\end{array}$ & - & $\begin{array}{c}\mathrm{r}=0,982^{* *} ; \\
\mathrm{p}<0,001\end{array}$ & $\begin{array}{c}\mathrm{r}=0,974^{* *} \\
\mathrm{p}<0,001\end{array}$ & - \\
\hline $\begin{array}{l}\text { Багатомірний } \\
\text { дисперсійний } \\
\text { аналіз (MANOVA) }\end{array}$ & & \multicolumn{3}{|c|}{$\mathrm{p}=0,971$} & \multicolumn{3}{|c|}{$\mathrm{p}=0,986$} \\
\hline $\begin{array}{l}\text { Кут між основними } \\
\text { маніпуляторами } \\
\text { град. }(n=14)\end{array}$ & $\begin{array}{l}(\mathrm{M} \pm \mathrm{SD}) \\
\text { Min-max }\end{array}$ & $\begin{array}{c}57,29 \pm 6,764 \\
44-65\end{array}$ & - & - & $\begin{array}{c}62,31 \pm 7,35 \\
55-71\end{array}$ & - & - \\
\hline $\begin{array}{l}\text { Відстань між } \\
\text { центрами кистей } \\
\text { хірурга, см (n=25) }\end{array}$ & $\begin{array}{l}(\mathrm{M} \pm \mathrm{SD}) \\
\text { Min-max }\end{array}$ & $\begin{array}{c}38,08 \pm 2,8 \\
33-41\end{array}$ & $\begin{array}{c}40,94 \pm 3,02 \\
36-45\end{array}$ & $\begin{array}{c}30,50 \pm 3,42 \\
25-34\end{array}$ & $\begin{array}{c}39,1 \pm 4,23 \\
34-43\end{array}$ & $\begin{array}{c}35,4 \pm 4,2 \\
31-39\end{array}$ & $\begin{array}{c}34,44 \pm 6,27 \\
29-41\end{array}$ \\
\hline \multirow{2}{*}{$\begin{array}{l}\text { Кореляція за } \\
\text { Пірсоном } \\
\text { у підгрупах } \\
\text { (двосторонній } \\
\text { рівень значущості) }\end{array}$} & Гіперст. & $\begin{array}{c}\mathrm{r}=0,960 * * \\
\mathrm{p}<0,001\end{array}$ & - & - & $\begin{array}{c}\mathrm{r}=0,995^{* *} ; \\
\mathrm{p}<0,001\end{array}$ & - & - \\
\hline & Астен. & $\begin{array}{c}\mathrm{r}=0,953^{* *} ; \\
\mathrm{p}<0,001\end{array}$ & $\begin{array}{c}\mathrm{r}=0,986 * * \\
\mathrm{p}<0,001\end{array}$ & - & $\begin{array}{c}\mathrm{r}=0,952^{* *} ; \\
\mathrm{p}<0,001\end{array}$ & $\begin{array}{c}\mathrm{r}=0,963^{* *} \\
\mathrm{p}<0,001\end{array}$ & - \\
\hline \multirow{2}{*}{$\begin{array}{l}\text { Багатомірн. } \\
\text { дисперс. аналіз } \\
\text { (MANOVA), } \\
\text { критерій Тьюкі }\end{array}$} & Гіперст. & $\mathrm{p}=0,002$ & - & - & $\mathrm{p}=0,034$ & - & - \\
\hline & Астен. & $\mathrm{p}<0,001$ & $\mathrm{p}<0,001$ & - & $\mathrm{p}=0,033$ & $\mathrm{p}<0,001$ & - \\
\hline $\begin{array}{l}\text { Дистанція між } \\
\text { лапароск. з кутом } \\
\text { лінзи } 0^{\circ} \text { та опер. } \\
\text { ділянки, см (n=14) }\end{array}$ & $\begin{array}{l}(\mathrm{M} \pm \mathrm{SD}) \\
\text { Min-max }\end{array}$ & $\begin{array}{c}3,41 \pm 0,478 \\
2,7-4,1\end{array}$ & - & - & $\begin{array}{c}3,54 \pm 0,47 \\
3,0-4,1\end{array}$ & - & - \\
\hline $\begin{array}{l}\text { Дистанція між } \\
\text { лапароск. } 3 \text { кутом } \\
\text { лінзи } 30^{\circ} \text { та опер. } \\
\text { ділянки, см (n=14) }\end{array}$ & $\begin{array}{l}(\mathrm{M} \pm \mathrm{SD}) \\
\text { Min-max }\end{array}$ & $\begin{array}{c}3,34 \pm 0,728 \\
2,5-4,5\end{array}$ & - & - & $\begin{array}{c}3,51 \pm 0,61 \\
2,9-4,1\end{array}$ & - & - \\
\hline
\end{tabular}

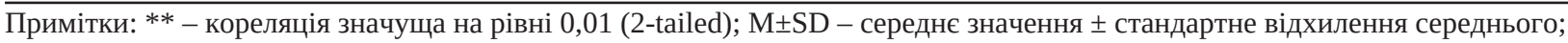
Min-max - мінімальне-максимальне значення. 
операційного втручання збільшення чи зменшення відстані між портами, залежно від типу статури, не впливає на доступність до об’єкта операції.

Таким чином, відстань між портами, а, отже, й кут між основними робочими інструментами, суттєво не погіршують умови доступності до цільового органа. Це підтверджує той факт, що при нормостенічному варіанті статури кут між основними робочими інструментами при власному способі встановлення портів для операції в середньому становить $(62,31 \pm 7,35)^{\circ}[55-71]^{\circ}$ та $є$ більшим порівняно з середнім значенням кута при “французькому” способі - $(57,29 \pm 6,764)^{\circ}[44-65]^{\circ}\left(\mathrm{p}<0,001^{*}\right)$, хоча обидва способи мають спільні точки локалізації портів, призначених для основного маніпулятора та лапароско- па, а відрізняються лише локалізацією допоміжних портів. При цьому площа візуалізації при порівнянні значень нормостенічного варіанту для власного способу в середньому становить $(13,31 \pm 3,76)$ см² $^{2}$ та $є$ більшою порівняно з показником “французького” способу $(9,54 \pm 2,27)$ см$^{2}\left(\mathrm{p}<0,001^{*}\right)$.

Порівняння параметрів власного способу з параметрами решти способів симультанних операційних втручань проведено шляхом дисперсійного аналізу з повторними вимірюваннями.

При порівнянні оцінених маргінальних середніх значень (рис. 3,4$)$ площі зони візуалізації власного способу - $(12,44 \pm 4,01)^{* *} \mathrm{~cm}^{2}(\mathrm{n}=156)$ та “французького” способу ЛХ - $(9,54 \pm 2,27)^{* *}$ см$^{2}$ виявлено статистично значущу різницю $(p=0,715)$.

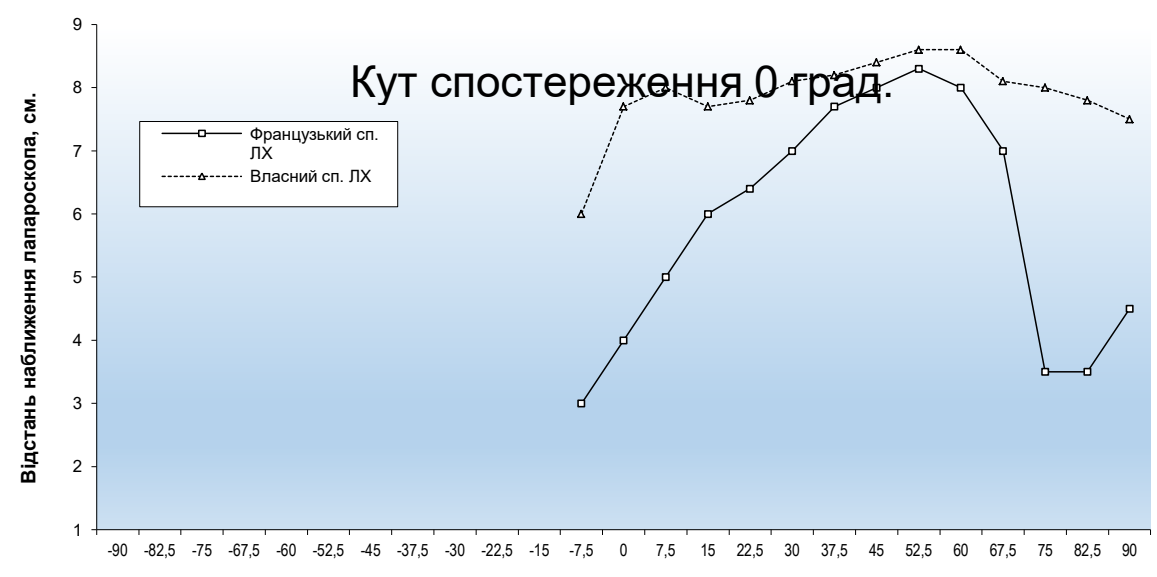

Кут положення осі цільового органа при симультанних операційних втручаннях

Примітка. * - дисперсійний аналіз із повторними вимірюваннями.

Рис. 3. Показники відстані наближення ендоскопа для кожного зі способів симультанних операцій при застосуванні лапароскопів із кутом спостереження $0^{\circ}$.

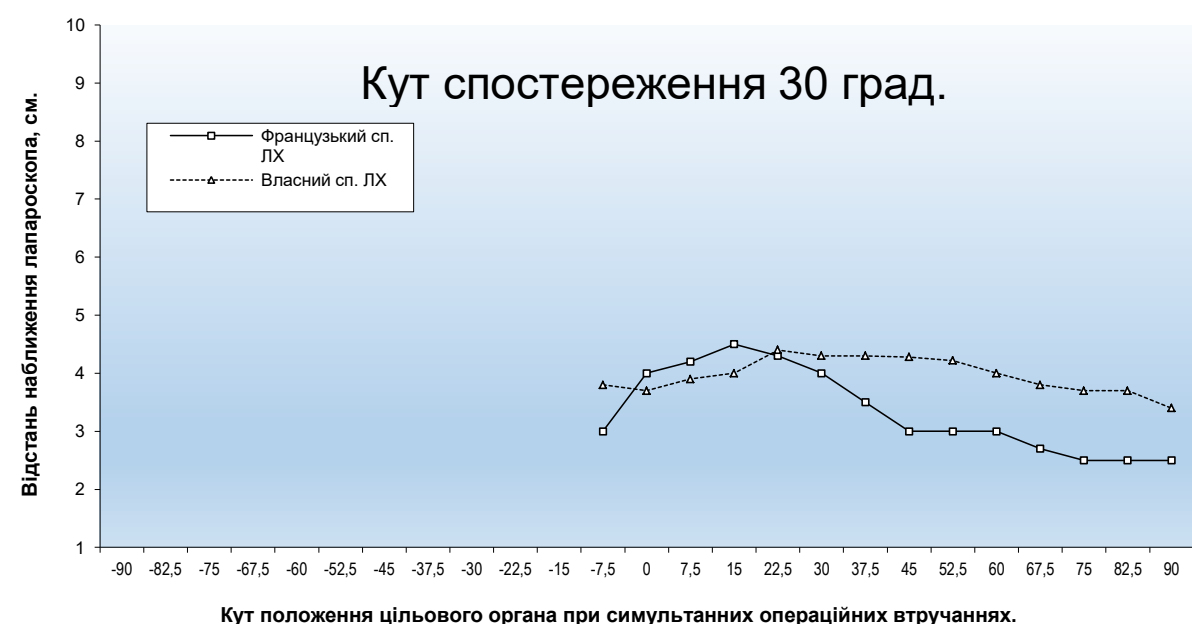

Примітка. * - дисперсійний аналіз із повторними вимірюваннями.

Рис. 4. Показники відстані наближення ендоскопа для кожного зі способів симультанних операцій при застосуванні лапароскопів із кутом спостереження $30^{\circ}$.

\footnotetext{
* - t-тест для парних вибірок

** $\mathrm{M} \pm \mathrm{SE}$ - значення \pm стандартна похибка середнього значення.
} 
При застосуванні лапароскопа з кутом спостереження $0{ }^{\circ}$ відстань наближення лапароскопа при власному способі доступу в середньому становить $(3,54 \pm 0,47)$ см $[3,0-4,1]$ см та є достовірно більшою порівняно 3 “французьким” способом, середнє значення дослідного параметра якого становить - $(3,41 \pm 0,478)$ см $[2,7-4,1]$ см $(\mathrm{p}<0,001)$. Відстань наближення лапароскопа при власному способі доступу в середньому становить $(3,51 \pm 0,61)$ см $[2,9-4,1]$ см та $є$ достовірно більшою порівняно 3 “французьким” способом, середнє значення дослідного параметра якого становить $-(3,34 \pm 0,728)$ см $[2,5-4,5]$ см $(\mathrm{p}<0,001)$.

Тому з огляду на деталізацію зображення, широту огляду, панорамність огляду ефективнішим $€$ розроблений спосіб симультанних операційних втручань, адже при достатньому наближенні до об’єкта операції зменшується ймовірність пошкоджень структур гепатодуоденальної зв'язки, а також структур трикутника, в якому проводиться крурорафія, пов'язаних із недостатньою візуалізацією, а достатня при цьому панорамність дає можливість контролювати рух маніпуляторів.

Окрім того, встановлено, що застосування лапароскопа з кутом спостереження $30^{\circ}$ для “французького” та власного способів симультанного операційного лікування забезпечує більш оптимальні умови порівняно з лапароскопом, кут спостереження якого становить $0^{\circ}$.

Таким чином, враховуючи показник доступності до об'єкта операції, можливості деталізації структур при умовах коли маніпуляції обмежені у зв'язку з набряком тканин та їх щільністю, що знижує податливість останніх, найоптимальнішим методом симультанних операційних втручань при гострих хірургічних патологіях $є$ власний спосіб.

Узагальнюючи результати можна стверджувати, що - розроблені нові критерії вивчення параметрів операційного доступу (які доповнюють загальноприйняті положення про операційний доступ в ендохірургії та характеризують ергономічні особливості маніпуляцій інструментами і враховують обмеження доступності до об’єкта втручання) у поєднанні з відомими параметрами, забезпе-

\section{СПИСОК ЛІТЕРАТУРИ}

1. Prophylaxis of post-ERCP pancreatitis: European Society of Gastrointestinal Endoscopy (ESGE) Guideline - updated June 2014 / J. M. Dumonceau, A. Andriulli, B. J. Elmunzer [et al.] // Endoscopy. - 2014. - Vol. 46. - P. 799-815.

2. GallRiks. Annual report. - 2016. - URL: http://www.ucr. uu.se/gallriks/fou/arsrapporter [accessed 31 May 2018].

3. Freeman M. L. Post-ERCP pancreatitis: patient and technique-related risk factors / M. L. Freeman // JOP. - 2002. Vol. 3. - P. 169-176. чили можливість порівняння власного способу 3 “французьким” способом симультанних операційних втручань за якістю доступу та ергономічними умовами виконання операції при різних хірургічних патологіях, виключно гострі:

- за результатами дослідження встановлено, що оцінене маргінальне середнє значення площі зони візуалізації при власному способі симультанних операційних втручань становить $(12,44 \pm 4,01)$ см² $^{2}$ та $€$ більшим на 30,4 \% за відповідний показник “французького” способу - $(9,54 \pm 2,27)$ см$^{2}(\mathrm{p}=0,715)$;

- при застосуванні лапароскопа з кутом спостереження $0{ }^{\circ}$ відстань наближення лапароскопа при власному способі доступу в середньому становить $(3,54 \pm 0,47)$ см та є більшою на 3,8 \% порівняно з середнім значенням дослідного параметра при “французькому” способі $(3,41 \pm 0,478)$ см (p=0,295);

- при застосуванні лапароскопа з кутом спостереження $30^{\circ}$ відстань наближення лапароскопа при власному способі доступу в середньому становить $(3,51 \pm 0,61)$ см та є більшою на 5,09 \% порівняно з показником “французького” способу $(3,34 \pm 0,728)$ см $(\mathrm{p}<0,001)$.

Висновки. Таким чином, отримано нові дані, які підтверджують гіпотезу, що досліджувані способи виконання симультанних операційних втручань відрізняються за доступністю до об'єкта операції та можливостями візуалізації. Також такі дані підтверджують, що власний спосіб лікування ЖKX і ГСОД, з огляду на досліджувані параметри, $є$ оптимальнішим порівняно 3 класичними “французьким” способом, оскільки є не менш комфортним, при цьому дає можливість виконати симультанне лікування ЖКХ і ГСОД без збільшення ризиків.

У підсумку власний спосіб забезпечує підвищення безпеки маніпуляцій при виконанні лапароскопічної холецистектомії симультанно в умовах гострого і хронічного холециститу за рахунок кращої доступності до об'єкта операції, меншого фізичного навантаження та відповідно - емоційного напруження хірурга, що зменшує ймовірність помилки при виконанні операції.

4. Risk factors for post-ERCP pancreatitis: a systematic review of clinical trials with a large sample size in the past 10 years / J. J. Chen, X. M. Wang, X. Q. Liu [et al.] // Eur. J. Med. Res. 2014. - Vol. 15. - P. 19-26.

5. Incidence rates of post-ERCP complications: a systematic survey of prospective studies / A. Andriulli, S. Loperfido, G. Napolitano [et al.] // Am. J. Gastroenterol. - 2007. - Vol. 102 (8). P. 1781-1788.

6. Cotton, Peter B. (2013-05-31). "ERCP (Endoscopic Retrograde 
Cholangio-Pancreatography)". Medical University of South Carolina (MUSC) Digestive Disease Center. Retrieved 2013-06-09.

7. Sharon Begley; Toni Clarke (20 February 2015). "FDA knew devices spread fatal 'superbug' but does not order fix". Reuters. Retrieved 20 February 2015.

8. URL: https://www.cochranelibrary.com/cdsr/doi/10.1002/ 14651858. CD007345.pub2/full

9. Brand M. Antibiotic prophylaxis for patients undergoing elective endoscopic retrograde cholangiopancreatography" / M. Brand, D. Bizos, P. O'Farrell Jr // Cochr. Database Syst. Rev. - 2010. - Vol. 10. - CD007345. DOI:10.1002/14651858. CD007345.pub2. PMID 20927758.

\section{REFERENCES}

1. Dumonceau, J.M., Andriulli, A., Elmunzer, B.J., Mariani, A., Meister, T., Deviere, J., ..., \& Kapral, C. (2014). European Society of Gastrointestinal Endoscopy. Prophylaxis of post-ERCP pancreatitis: European Society of Gastrointestinal Endoscopy (ESGE) Guideline. Updated June 2014. Endoscopy, 46, 799-815. 2. GallRiks. Annual report 2016. Retrieved from: http: //www. ucr.uu.se/gallriks/fou/arsrapporter.

3. Freeman, M.L. (2002). Post-ERCP pancreatitis: patient and technique-related risk factors. JOP, 3, 169-176.

4. Chen, J.J., Wang, X.M., Liu, X.Q., Li, W., Dong, M., Suo, Z.W., ..., \& Li, Y. (2014). Risk factors for post-ERCP pancreatitis: a systematic review of clinical trials with a large sample size in the past 10 years. Eur. J. Med. Res., 15, 19-26.

5. Andriulli, A., Loperfido, S., Napolitano, G., Niro, G., Valvano, M.R., Spirito, F., ..., \& Forlano, R. (2007). Incidence rates of postERCP complications: a systematic survey of prospective studies. Am. J. Gastroenterol., 102 (8), 1781-1788.

6. Cotton, P.B. (2013). ERCP (Endoscopic Retrograde Cholangio-Pancreatography). Medical University of South Carolina (MUSC) Digestive Disease Center. Retrieved 2013-06-09.

7. Begley, S., Clarke, T. (2015). FDA knew devices spread fatal superbug but doesn't order fix. Reuters. Retrieved 20 February 2015.

8. https://www.cochranelibrary.com/cdsr/doi/10.1002/14651858. CD007345.pub2/full

Електронна адреса для листування: galej.mm@gmail.com
10. Колкін Я. Г. Удосконалення лапароскопічних і традиційних відкритих втручань у хворих на доброякісні осередкові утвори печінки / Я. Г. Колкін, В. В. Хацко, О. Д. Шаталов // Шпитальна хірургія. - 2010. - № 3. - С. 39-42.

11. Досвід лапароскопічних операцій у хворих на жовчнокам'яну хворобу / Ю. С. Семенюк, О. В. Потійко, I. В. Сидорук [та ін.] // Шпитальна хірургія. Журнал імені Л. Я. Ковальчука. - 2015. - № 3. - С. 33-36. DOI: https://doi. org/10.11603/2414-4533.2015.3.5025.

12. Симультанні лапароскопічні операції 3 приводу жовчокам'яної хвороби та грижі передньої черевної стінки / М. Ю. Ничитайло, М. С. Загрійчук, І. І. Булик [та ін.] // Клінічна хірургія. - 2015. - № 3. - С. 21-23.

8. Brand, M, Bizos, D, \& O'Farrell, P., Jr (2010). Antibiotic prophylaxis for patients undergoing elective endoscopic retrograde cholangiopancreatography. Cochr. Database Syst. Rev., 10, CD007345. DOI:10.1002/14651858.CD007345.

10. Kolkin, Ya.H., Hatsko, V.V., Shatalov, O.D., Gredzhev, F.A., Kuzmenko, O.Ye., Pishchansky, R.Ye.,, ..., \& Bazian, N.K. (2010). Udoskonalennia laparoskopichnykh i tradytsiinykh vidkrytykh vtruchan u khvorykh na dobroiakisni oseredkovi utvory pechinky [Improvement of laparoscopic and traditional open interventions in patients with benign focal liver tumors]. Shpytalna khirurhiia - Hospital Surgery, 3 [in Ukrainian].

11. Semeniuk, Yu.S., Potiyko, O., Sydoruk, I., Ordynskyi, Yu.M., Fedoruk, V., Minich, V.G., ..., \& Andrushkiv, N. (2015). Dosvid laparoskopichnykh operatsii u khvorykh na zhovchnokamianu khvorobu [Experience of laparoscopic operations in patients with gallstone disease]. Shpytalna khirurhiia. Zhurnal imeni L.Ya. Kovalchuka - Hospital surgery. Journal named after L. Ya. Kovalchuk, 3, 33-36 DOI: https://doi.org/10.11603/24144533.2015.3.5025 [in Ukrainian].

12. Nychytailo, M.Iu., Zahriichuk, M.S., Bulyk, I.I., Masiuk, Iu.I., Homan, A.V., \& Kondratiuk, V.A. (2015). Symultanni laparoskopichni operatsii z pryvodu zhovchokamianoi khvoroby ta hryzhi perednoi cherevnoi stinky [Simultant laparoscopic operations for biliary calculi disease and hernia of the anterior abdominal wall]. Klinichna khirurhiia - Clin. Surg., 3, 21-23 [in Ukrainian].

Отримано 08.02.2021

\section{M. HALEI ${ }^{1}$, O. I. DZIUBANOVSKYI ${ }^{2}$, M. O. ONYSKIV²}

Volynian Regional Clinical Hospital ${ }^{1}$

I. Horbachevsky Ternopil National Medical University ${ }^{2}$

\section{COMPARATIVE ASSESSMENT OF IMAGING IN THE PERFORMANCE OF SIMULTANEOUS LAPAROSCOPIC TREATMENT OF GALLSTONE DISEASE AND HIATAL HERNIA}

\footnotetext{
The aim of the work: to determine and evaluate the visualization in the performance of conventional laparoscopic operations and simultaneous laparoscopic operations for the treatment of gallstone disease and hiatal hernia; identify the advantages and disadvantages of methods; assess the impact of the choice of laparoscopic techniques on ergonomics during surgery.

Materials and Methods. 156 patients were treated in Volynian Regional Clinical Hospital

Laparoscopic Surgery Unit during the period from 2013 to 2019, who underwent laparoscopic crurography with Toupet fundoplication and simultaneous laparoscopic cholecystectomy using our own developed technique. Comparison with the results of treatment of gallstone disease using the "French" method. The method with the null hypothesis, Pearson, Tukey, Mann-Whitney analysis were used. Results and Discussion. The difference between the ports for asthenic and hypersthenic physiques was $4.4 \mathrm{~cm}$ and $3.0 \mathrm{~cm}$, visualization area was $(12.44 \pm 4.01)$ and $(9.54 \pm 2.27) \mathrm{cm}^{2}$ (which is statistically significant $(\mathrm{p}=0.715)$ ), the angle between the instruments
} 
was $(62.31 \pm 7.35)^{\circ}$ and $(57.29 \pm 6.764)^{\circ}$, the distance between the laparoscope and the object of operation was (3.54 \pm 0.47$) \mathrm{cm}$ and $(3.41 \pm 0.478) \mathrm{cm}$ for the studied and control groups, respectively. Simultaneous laparoscopic intervention did not impairs visualization and increases comfort during simultaneous surgery compared to French cholecystectomy. The use of the developed simultaneous technique did not worsed the postoperative consequences. The technique developed on the basis of Volynian Regional Clinical Hospital Laparoscopic Surgery Unit is rather effective and suitable for use.

Keywords: gallstone disease; hiatal hernia; simultaneous surgery; laparoscopy.

\title{
Н. М. ГАЛЕЙ
}

КП "Волынская областная клиническая больница"1

Тернопольский национальный медицинский университет имени И. Я. Горбачевского МОз Украины²

\section{СРАВНИТЕЛЬНАЯ ОЦЕНКА ВИЗУАЛИЗАЦИИ ПРИ ВЫПОЛНЕНИИ СИМУЛЬТАННОГО ЛАПАРОСКОПИЧЕСКОГО .ЛЕЧЕНИЯ ЖЕЛЧНОКАМЕННОЙ БОЛЕЗНИ И ГРЫЖИ ПИЩЕВАРИТЕЛЬНОГО ОТВЕРСТИЯ ДИАФРАГМЫ}

\begin{abstract}
Цель работы: определить и оценить визуализацию при выполнении обычных лапароскопических операций и симультанных лапароскопических операций при лечении желчнокаменной болезни (ЖКБ) и грыжи пищеварительного диафрагмального отверстия (ГПОД). Определить преимущества и недостатки методик. Оценить влияние выбора техники лапароскопических операций на эргономику при выполнении операционного приема.

Материалы и методы. На базе ВОКБ ОИМДЛ в период с 2013 по 2019 г. 156 пациентов прошли лечение, которым выполнялась лапароскопическая крурорафия с фундопликацией по Тупэ и симультанная лапароскопическая холецистэктомия с использованием собственной разработанной техники. Сравнение с результатами лечения ЖКБ “французским” методом. Использовано методику с нулевой гипотезой, анализ по Пирсону, Тюки, Манна-Уитни.

Результаты исследований и их обсуждение. Разница расстояния между портами для астенического и гиперстенического типа телосложения составила 4,4 см и 3,0 см, зона визуализации $(12,44 \pm 4,01)$ и $(9,54 \pm 2,27)$ см$^{2}$ (что статистически значимо $(\mathrm{p}=0,715))$, угол между инструментами $(62,31 \pm 7,35)^{\circ}$ и $(57,29 \pm 6,764)^{\circ}$, расстояние приближения лапароскопа к объекту операции составляет $(3,54 \pm 0,47)$ см и $(3,41 \pm 0,478)$ см для исследуемой и контрольной групп соответственно. Выполнение симультанного лапароскопического вмешательства не ведет к ухудшению визуализации и увеличивает комфорт при симультанной операции по сравнению с холецистэктомией “французским” методом. Использование собственной симультанной техники не ведет к ухудшению послеоперационных последствий. Разработанная на базе ВОКБ ОИМДЛ методика является достаточно эффективной и пригодной к использованию.
\end{abstract}

Ключевые слова: желчнокаменная болезнь; грыжи пищеварительного отверстия диафрагмы; симультанная хирургия; лапароскопия. 